\title{
Project-based Language Learning: Email Exchanges between Non-native English Speakers
}

\author{
Sue Wang \\ School of Foreign Studies, Central University of Finance and Economics, Beijing, China
}

\begin{abstract}
Chinese and Korean EFL college students. With the non-native speakers of English far outnumbered the native speakers, it is necessary to investigate the interactions between these non-native speakers whose communication is made possible only through English. 36 Chinese EFL college students participated in this e-pal project with a group of 28 Korean EFL college students. This paper reported the Chinese students' perceptions and their attitudes towards interactions through email exchange with their non-native counterparts. Implications of using project as an approach in EFL learning and teaching is also discussed.
\end{abstract}

Index Terms -Email, non-native English speakers, project-based learning

\section{INTRODUCTION}

Technology opened up many possibilities for cross-cultural communication and consequently it has drawn the attention of many scholars including scholars from the language field. Computer-mediated communication has been a focus for a long time in applied linguistics. Issues between the communication between non-native English speakers (NNES) and native English speakers (NES) through technology has also been explored by many researchers. Electronic mail as one of the internet products has been found useful in language learning. It has been examined by a number of researchers (Liaw, 1998; Liaw and Johnson, 2001; Liu, 2011; Stockwell and Levy, 2001).

Liaw (1998) conducted a study with his EFL students to explore the use of emails in writing. He matched the students in two classes and asked them to communicate through email across one semester. The findings suggested that the students generally thought positively of the project though there was no obvious improvement in terms of language skills after the ending of the project. Researchers also investigated the use of email as a way to enhance the language learning of NNES through their interactions with NES (Gu \& Zhu, 2002; Wu, 2015). Gu and Zhu (2002) reported a case study between a group of Chinese college students and their American counterparts who conducted a collaborative writing project via internet. The authors examined the impacts of PBL, when combined with technology, on the EFL students' motivation and performance in language learning. The authors reached the conclusion that project-based language learning together with technology could be effective in motivating the Chinese EFL learners. Ma (2006) investigated four ESL students' perceptions of email communication in English in Canada. The students were found generally positive towards this experience reporting that the exchange not only provided them opportunities to practice their language regularly but also beneficial in terms of cultural communication and relationship building. Shang (2007) found that the EFL students who participated in the email exchange improved in terms of syntactic complexity and grammatical accuracy but not lexical density. It was also found students had a positive attitude towards this email exchange approach. Similarly, Na and Kim (2010) also went towards this direction and examined whether the language improved during the exchange process. Different from the findings by Shang (2007), the authors did not find significant improvement in grammatical accuracy. The students did report, though, that the email exchange reduced their anxiety level and they became more motivated in communication not only for the tasks assigned to them but also for personal matters. This line of research continued. For instance, Dunne (2014) examined the email exchange between the beginner-level EFL learners in Japan and Chile with a task-based framework. The author discussed the positive effects of this project in spite of the difficulties in terms of logistical and technical aspects. Wu (2015) conducted a collaborative email exchange project between two groups of secondary-school students in Taiwan and United States. The findings indicated that the email exchange improved students' attitudes in language and cultural learning.

It is also found that many of the studies mentioned above adopted the Project-Based Learning (PBL) approach. PBL as a learner-centered approach, has been applied to ESL/EFL (English as a second/foreign language) teaching/learning in the 1980's in Europe and later 1990's in North-America. In Beckett (1999), PBL in second/foreign language field is defined as a series of individual or group activities that involve language/content learning through planning, researching (empirical and/or document), analyzing and synthesizing data, and reflecting on the process and product orally and/or in writing by comparing, contrasting, and justifying alternatives (p. 4). Since then, an increasing number of studies on PBL as an approach in ESL/EFL learning and instruction has been published (Alan \& Stoller, 2005; Beckett, 2005). In China, the application of PBL in language studies started mostly around the 2000s and PBL pedagogy and research is drawing the attentions of more and more researchers, particularly in the past several years (Yu, 2017). These studies explored the different aspects of PBL in language learning by offering frameworks for it (Beckett \& Slater, 2005; Zhang, 2015) or 
give an overview of the studies in it (Beckett \& Miller, 2006), or explore the specific factors in the application of PBL. For instance, Xia and Zhang (2017) investigated the learner efforts and factors that affect the efforts when PBL was applied as the pedagogy. In general, these studies have demonstrated that PBL could be used as an effective approach in language learning and teaching.

With the NNES far outnumbered the native speakers, more and more English as a foreign language (EFL) speakers are communicating through English, which is now sometimes described as "English as an international language" (EIL) or "English as lingua franca" (ELF). In this context, it is necessary to investigate the interaction between these nonnative speakers whose communication is made possible only through English. However, there is not much literature on the email exchange between NNES in different nations (Dunne, 2014; Fedderholdt, 2001). This study tends to address the issues in the cross-cultural communication between NNES in different nations. Since email as a communication tool has become part of the students' daily life in both in China and Korea, a project is initiated to encourage authentic communication between Chinese and Korean students. More specifically, the present study attempts to investigate the Chinese college students' experience towards their Korean counterparts in computer-mediated cross-national writing activities. This study focused on the following research question: how do the Chinese students perceive the email exchange with their Korean counterparts in English?

\section{RESEARCH DESIGN}

\section{A. Participants}

This project is conducted between college students in China and Korea. There were 36 Chinese EFL college students and 28 Korean EFL college students participated in the study. The Chinese students were second year English majors in a top university in Northern China. At the time of the study, the Chinese participants were taking a course called Practical Writing. The author, who was also the instructor of the writing course, made English email writing part of the course taking into consideration the fact that email writing would be part of their professional life when they go to work. 28 of the Chinese students chose their partners after they read the self-introduction from their Korean counterparts. The rest chose to pair up with another group of Korean students and therefore is not in the scope of this paper. The 28 Korean EFL college students participated in the e-paling project were taking a culture course and they came from different academic departments at the time of the study. Both the Chinese and Korean students were required to write at least one email to their partners every two weeks so that the students would not take it as an extra burden. The pairingup between the Chinese and Korean students took some time and most started their first email exchange with their epals from early April and stopped in middle June before the students on both sides started to prepare for their final examination.

\section{B. Data Collection}

Data collected for this study include a questionnaire before the start of the project and a questionnaire after the end of the project. The questionnaire before the start of the project mainly focused on students' previous language learning experience and English email writing experience. The post-project questionnaire mainly focused on the students' experiences towards the project. Besides these questionnaires, related information such as the email samples written by the Chinese students were also collected. Altogether, 101 email entries from the Chinese participants were collected as part of the data. These data were analyzed following qualitative analysis methods (Patton, 2002). The following are part of the findings from the project.

\section{FINDINGS}

\section{A. The Paradox of Net Generation}

Even in today's China where the Chinese participants actually grow up with technology, writing emails in English is found to be rarely done by the Chinese participants. For the Chinese participants in this study, everyone has a cell phone and most of them cannot live without it. They are very good at texting messages to their friends and they use all kinds of online social networking to keep in touch with their friends. However, when it comes to using computer for English learning, it can be seen there is a lot to be done to fully take advantage of technology. Among the Chinese participants, only about $15 \%$ of the students had previous experiences of email communication in English. And over $80 \%$ of the Chinese students mentioned that they were not very experienced with using computer for English writing. Therefore the Chinese participants in the study, on the one hand, were part of the net generation but at the same time, most lacked the chance of communicating in English through email writing.

\section{B. The English Email Exchange with NNES: Meaningful}

From the post-project survey, most of the Chinese participants considered it was a meaningful activity for them to get the chance of communicate in English with a real person in the real world. When being asked about their opinion of the English email writing experience, many thought positively about it:

"I think it is a very meaningful activity. It is necessary for us college students to know more about the peers in other countries and also communication draw us closer. Personally I think it is very important for this communication being 
kept in a longer term and guarantee the regular contact between the key pals."

"It is such a pleasure for us to have this opportunity to communicate with Korean fellow students, from which we actually learned a lot."

Similar opinion was echoed by other students as well, for instance: "I think communicate with NNES is also beneficial. We ourselves are also NNES and we can find our weaknesses and strengths and also it is helpful to learn more about the culture of the other country."

Even with Internet available, it turned out that, for many students, this was their first time to write to someone in another country. Through this activity, they learned about Korean's students' life and culture. The study found that most of the Chinese students consider that email exchange between NNES is a meaningful activity because it can promote cultural exchange between different nations.

\section{The English Email Exchange with NNES: Disappointed}

While most students agreed that the project was meaningful, there were also some students who had less pleasant experiences due to the particular situation they found themselves in. For instance, one student mentioned that "The Korean students sometimes even get stuck in making simple introduction of themselves with simple sentences. Of course there... this is not discriminating their English ability, but to honestly point out it would work out better if both the levels matched up." It seems that the low proficiency of the partner became a serious barrier in communication. The Chinese student felt that she/he could not communicate well with the partner because the other was really insufficient in the proficiency of the language level. Another student was also quite unsatisfied with her partner: "It's a little boring when your partner takes no interest in your emails. Can you imagine how disappointed I was whenever I received an email less than 50 words compared to my lengthy and elaborate emails...I want to say to my e-pal: sorry to disturb you, I didn't mean to. I can't see any efforts he put in the e-paling. But for my loving professor, I would have said good bye to him long long ago." If the first student's dissatisfaction here was caused by language issues, the second student's problem here was more of an attitude issue. The partner did not show the proper etiquette in this cross-cultural communication and led to the unpleasant experience of the other.

\section{Language Concerns: Mixed Reactions}

Some Chinese participants expressed their concern about the purity of the English language use when the interaction was conducted in a language which neither side had fully mastered. Some worried that communicating with another NNES, particularly with someone who has lower language proficiency level, would only do harm to their language learning. These students believed that communicating with native speakers would improve their language use in a more effective way. In contrast with such kind of concerns, there were also some other students who were more open-minded towards the language errors and communication breakdowns caused by the limited language proficiency on both sides. These students thought it was a great chance to learn about another country and another culture. Even there were some issues with grammar or use of words or similar issues, they found ways to get around it and kept the communication going. That is to say, some students were less tolerant towards the fact that they were communicating with a NNES while others were more open to this.

\section{DISCUSSION AND IMPLICATIONS FOR EFL INSTRUCTORS}

\section{A. Take Better Advantage of the Net Generation}

Despite the fact that the Chinese participants grow up as the net generation and they are technology savvy in Chinese-mediated communication, it is a different story when it comes to communicating through English. For the Chinese participants, only very few took advantage of internet and wrote English emails to communicate with other English speakers, native or non-native. There are two reasons for that. First is that the students simply did not have a chance to have these kind of authentic communication in their life. In addition, many students still take language learning as a subject for them, not fully understand the practical use of it in their future life. It would be helpful for instructors to provide opportunities for students to get a first-hand experience of writing in another language. Also the students should be encouraged to keep using the English language for authentic purposes. Particularly with the net generation, email exchange could be better explored as part of language instruction. More opportunities should be created for the students to conduct authentic communications with both NES and NNES as much as possible.

\section{B. Language Attitude: Who Is the Superior?}

The study found that many Chinese participants showed their concern toward the correctness and appropriateness of email communication with other NNES through English. Students' perceptions towards themselves, towards NES and NNES will be discussed in the following because they are interrelated.

The first is the Chinese participants' perceptions towards their own language learning. In the pre-project questionnaire, most Chinese participants described their English proficiency as low or intermediate. Many were not very confident about their English level and they still focused on a lot learning for examinations, which by nature would stress the grammar and correctness of the target language output. With such a belief, the students thought that by communicating with NES, they would have models to follow and they could contact higher-quality English use. In 
general, they hold the belief of NES superiority in language learning. Compared to the positive attitude towards NES, it seemed that many students held negative beliefs towards other NNES in English use. NNES by definition is put in an inferior position, including themselves. The students' concern is valid to some degree since the non-native speakers often produce what might be called "interlanguage", which can be confusing at least and might lead to frequent misunderstanding. The Chinese participants worried that the exposure to "incorrect" language use would corrupt or bring negative impact on their English use.

It should be argued here that while it is true that native speakers can provide higher quality language models for NNES such as the Chinese participants, the exposure would not affect the Chinese participants' language use. There are several reasons. The students were required to write at least one email to their partners every two weeks. This actually was a very tiny part of their language learning, particularly when these students majored in English. The author's argument is that while some of the Chinese participants hold the belief that impure email message produced by their Korean partners would affect their language negatively, the truth is the impact of such small amount of exposure would be insignificant. Another important point that should be made clear to the NNES is that with the increasing number of NNES who communicate through English, they should be more tolerant towards NNES, including themselves. The attention should be paid to the content of the messages rather than being critical of the form of the messages.

As Kachru (2011) has argued that in his series of works on World Englishes, English is not only the language used by the so-called NES, when the globalization has swept all most every corner of the world. English is also part of the identities of those bilingual or trilingual people, or those who have to use it in their work and life for various reasons. It is also advised that the instructors guide the students in developing inter-cultural communication strategies so that they could be more successful communicating through English in this global village. NNES should be guided to establish a more positive identities of themselves and other NNES, rather than being constrained by the deficiency model in which their ability to speak a second, or for some even third language, is not valued but being critically examined.

\section{Project Design and the Purpose of the Key-pal Project}

In this study, the Chinese participants were given the task of writing emails to a real person in another country. The authenticity of the task made it more interesting for the students, particularly at the very beginning. They all showed great interest and enthusiasm. However, because it was authentic communication, the process was actually jointly decided by the efforts from both sides. For the students who had positive experiences, many factors led to the successful experience of their email exchange: quick responses on both sides; equivalent language proficiency; effective communication strategies when there was misunderstanding and respect towards each other's culture, etc. Students who were more motivated with their language learning and better communication skills in general had positive experiences. At the same time, it also depended on the partner they happened to have. There was one particular student who wrote a number of email messages to his partner but did not get any response. It also happened the other way around: some Korean students cannot get response from their Chinese partners who were not motivated to do the e-paling even after repeated reminder from the instructor. Therefore, the design of the project is important. The implementation of the project also needs constant supervision and guide from the instructors on both sides. It might be helpful to ask the students to finish some specific tasks while at the same time let them freely discuss issues that they are interested in. Here, project-based language learning would be beneficial yet the logistics of the project management is important. The instructors of the project need to take multiple factors into consideration and monitor the project as it go along. This indeed would demand the instructors to switch their role from the traditional language teaching and learning class.

\section{CONCLUSION}

The study investigated the experience of a group of Chinese college students in a project-based language learning through e-paling between these students and their Korean counterparts. The study found that the email exchange provided an authentic way for the involved students to practice their English or learn more about culture and people of another country. The participants showed great interest in doing such email exchange and considered it as a meaningful activity. Most of the students agreed that this project-based language learning could be an effective way to learn language and practice cross-cultural communication. Some students might need to be better guided about the importance of NNES communication, particularly during the globalization background where the communication between NNES has been increasing.

At the same time, the study found that the project should be carefully designed so that the students would be motivated to continue their enthusiasm at the beginning of the project. The instructor is responsible to facilitate and supervise the writing process so that the problems came along with the project can be solved in a timely manner by the students and instructors on both sides. It is also helpful to further explore what makes the email exchange successful and what are the factors that hampered the successful communication between students so that measures could be taken.

Besides careful design of the project, the instructors planning to start such projects should also help their students develop useful communication strategies between NNES so that the students would be able to effectively use English as a medium of communication in future with other NNES in a variety of contexts. 


\section{ACKNOWLEDGEMENTS}

This paper is supported by Foreign Language Education Fund of China (\#GWYJYJJ2018B10) and School of Foreign Studies, Central University of Finance and Economics.

\section{REFERENCES}

[1] Alan, B., \& Stoller, F. L. (2005). Maximizing the benefits of project work in foreign language classrooms. English Teaching Forum, 43 (4), 10-21.

[2] Beckett, G. H. (1999). Project-based instruction in a Canadian secondary school's ESL classes: Goals and evaluations. Unpublished doctoral dissertation, University of British Columbia, Vancouver. Canada.

[3] Beckett, G. H. (2005). Academic language and literacy socialization through project-based instruction: ESL student perspectives and issues. Journal of Asian Pacific Communication, 15, 191-206.

[4] Beckett, G. H., \& Slater, T. (2005). The project framework: A tool for language, content, and skills integration. ELT Journal, 2, 108-116.

[5] Beckett, G. H., \& Miller, P. C. (Eds.). (2006). Project based second and foreign language education: Past, present and future. Greenwich, CT: Information Age Publishing.

[6] Dunne, B. G. (2014). Reflecting on the Japan-Chile Task-Based Tele-collaboration Project for Beginner-Level Learners, TESL Canada Journal, Vol.31, (8) p175-186.

[7] Fedderholdt, K. (2001). An email exchange project between non-native speakers of English. ELT Journal, Vol 55 (3), pp. 273 280.

[8] Gu, P., \& Zhu, M. (2002). Online English writing and project-based learning: A case study, Technology Enhanced Foreign Language Education, 88, 3-7.

[9] Kachru, Y. (2011). World Englishes: Contexts and relevance for language education. E. Hinkel (Ed.), Handbook of research in second language teaching and learning (pp. 155-172). Taylor \& Francis Routledge.

[10] Liaw, M.L. (1998) Using electronic mail for English as a foreign language instruction, System, 26, pp. 335-351

[11] Liaw, M.L., \& Johnson R.J. (2001) E-mail writing as a cross-cultural learning experience, System, 29, pp. 235-251

[12] Liu, Y. (2011). Power perceptions and negotiations in a cross-national email writing activity. Journal of Second Language Writing, 20, pp. 257-270.

[13] Ma, J. (2006). Second language learners' perceptions of email: Communication in English. Unpublished Master Thesis: Queen's University, Canada.

[14] Matsuda, A., \& Matsuda, P.K. (2010). World Englishes and the teaching of writing. TESOL Quarterly, 44(2), 369-374.

[15] McKay, S.L. (2011). English as an international lingua franca pedagogy. E. Hinkel (Ed.), Handbook of research in second language teaching and learning (pp. 122-139). Taylor \& Francis Routledge.

[16] Na, Y. H., \& Kim, H.S. (2010). Tracing L2 learners' accuracy development in CMC. English Language Teaching, 22(1), 195221.

[17] Patton, M.Q. (2002). Qualitative research \& evaluation methods (Third edition). Sage Publications, Thousand Oaks, CA.

[18] Shang H. (2007). An exploratory study of e-mail application on FL writing performance. Computer Assisted Language Learning 20, 1, pp. $79-96$.

[19] Stockwell, G. \& Levy, M. (2001). Sustainability of E-mail interactions between native speakers and nonnative speakers. Computer Assisted Language Learning, 14, pp. 419-442.

[20] Wu, F.H. (2015). Improving pupils' attitude to English learning and cultural understanding through email exchange: An action research project in a secondary school in Taiwan. Unpublished Doctoral Thesis: Durham University, United Kingdom.

[21] Xia, S., \& Zhang, W. (2017). Learners' efforts of the project-based language learning. Foreign Languages and their Teaching, 3, $78-88$.

[22] Yu, W. (2017). Students' perceptions of the impacts of project activities in learning, Experiencing New English, Foreign Languages in China, 14 (3), 82-91.

[23] Zhang, W. (2015). iPBL: A localized project-based English teaching and learning model, Foreign Languages in China, (12) 2 , $15-23$.

Sue Wang, Ed. D, is currently Associate Professor at School of Foreign Studies, Central University of Finance and Economics in Beijing, P. R. China. She has published books and papers on Chinese EFL students' oral and writing development. Her research interests also include discourse analysis, teacher development and translation studies. 